\title{
Evaluation of Herbicidal Potential of Depsides from Cladosporium uredinicola, an Endophytic Fungus Found in Guava Fruit
}

\author{
Livia S. de Medeiros, ${ }^{a}$ Olivia M. Sampaio, ${ }^{a}$ Maria Fátima das G. F. da Silva, ${ }^{a}$ \\ Edson Rodrigues Filho ${ }^{a}$ and Thiago André M. Veiga ${ }^{*, b}$
}

\author{
${ }^{a}$ Departamento de Química, Universidade Federal de São Carlos,13565-905 São Carlos-SP, Brazil \\ ${ }^{b}$ Instituto de Ciências Ambientais, Químicas e Farmacêuticas, Universidade Federal de São Paulo, \\ 09972-270 Diadema-SP, Brazil
}

\begin{abstract}
Dois produtos naturais produzidos por Cladosporium uredinicola, um fungo endofítico isolado da goiaba, tiveram seus efeitos sobre a fotossíntese avaliados. Os compostos inibiram o fluxo de elétrons (basal, fosforilante e desacoplado) de água a metilviologênio (MV). Esses compostos atuam como inibidores da reação de Hill em tilacóides de espinafre frescos. Esses policetídeos pertencem à classe dos depsídeos e inibiram o fluxo de elétrons das reações parciais do fotossistema II (PS II) de água a 2,5-dicloro-1,4-benzoquinona (DCBQ), de água a silicomolibdato de sódio ( $\mathrm{SiMo} \mathrm{Na}^{+}$), e ainda inibiram parcialmente de 1,5-difenilcarbazida (DPC) a 2,6-dicloroindofenol (DCPIP). Esses resultados estabeleceram que os sítios de inibição dos depsídeos estão localizados tanto no lado doador quanto no aceptor do PS II, entre $\mathrm{P}_{680}$ e $\mathrm{Q}_{\mathrm{A}}$. Medidas de fluorescência da clorofila a corroboraram para elucidar esse mecanismo de ação. Nenhum dos compostos inibiu o fluxo de elétrons no fotossistema I (PS I).
\end{abstract}

Two natural products produced by Cladosporium uredinicola, an endophytic fungus isolated from guava fruit, were evaluated for their effects on photosynthesis. Both of them inhibited electron flow (basal, phosphorylating, and uncoupled) from water to methylviologen (MV), acting as Hill reaction inhibitors in freshly lysed spinach thylakoids. These polyketides, belonging to depsides class, inhibited partial reactions of photosystem II (PS II) electron flow from water to 2,5-dichloro1,4-benzoquinone (DCBQ), from water to sodium silicomolybdate $\left(\mathrm{SiMo} \mathrm{Na}^{+}\right)$, and partially inhibited electron flow from 1,5-diphenylcarbazide (DPC) to 2,6-dichloroindophenol (DCPIP). These results established that the depsides sites of inhibition are located on the donor and acceptor sides of PS II, between $\mathrm{P}_{680}$ and $\mathrm{Q}_{\mathrm{A}}$. Chlorophyll a fluorescence measurements corroborated this mechanism of action. None of the tested compounds inhibited photosystem I (PS I) electron transport.

Keywords: endophyte, Cladosporium, depsides, Hill reaction inhibitors, photosystem II

\section{Introduction}

Extensive research has been carried out worldwide to find new effective and ecologically natural friendly alternatives due to ecological restrictions in applying synthetic herbicides. A possible solution is the use of weed pathogens for biological control, using fungal metabolites to produce new selective herbicides such as biolaphos. ${ }^{1}$ Therefore, these compounds could act as communicators between plants and fungi. ${ }^{2,3}$ The interests of chemical ecology are to describe the ecological interactions mediated

*e-mail: tveiga@unifesp.br by natural products and their potential application. ${ }^{3}$ The interactions depend on the organisms involved and their environments.

Natural products have an enormous diversity of chemical structures and could show modes of action different than the commercial herbicides, suggesting that they are ideal leads for new herbicide discovery. ${ }^{2,45}$ Recently, herbicidal activity of many natural products isolated from fungi, like stagonalide, ${ }^{6}$ stagonolide $\mathrm{H},{ }^{2}$ alternethanoxin $\mathrm{A}$ and $\mathrm{B},{ }^{7}$ lasiodiplodin, ${ }^{8}$ ascochlorin, ${ }^{9}$ ophiobolin $\mathrm{A},{ }^{10}$ deoxaphomin, ${ }^{11}$ and ascaulitoxin ${ }^{12}$ have been reported.

Depsides are natural aromatic polyketides, composed of two different types of moieties (for example, orcinol 
or $\beta$-orcinol units) connected by ester linkages. ${ }^{13}$ They are most often produced by lichens, but have also been isolated from higher plants, including species of Ericaceae, Lamiaceae, and Papaveraceae. ${ }^{14}$ These compounds have biological activities such as antibacterial, ${ }^{15}$ anticancer, ${ }^{16}$ and anti-HIV- $1 .{ }^{17}$ Additionally, depsides also have allelophatic activities. A number of metabolites and aqueous extracts of various lichens inhibited seed germination and growth of plants, thus representing potential leads for the developing of new herbicidal agents. ${ }^{18-20}$ Photosynthesis is a core physiological function of plants designed to safely convert solar energy into chemical units. Stresses (both biotic and abiotic) often affect the efficiency of this process and a number of herbicides having target photosystem I or II inhibit photosynthesis directly. However, photosynthesis can also be affected by herbicides that inhibit carotenoid synthesis and those causing lipid peroxidation (uncouplers and inhibitors of protoporphyrinogen oxidase). Also, herbicides inhibiting lipid synthesis (inhibitors of verylong-chain fatty acid synthase) also indirectly affect this process. ${ }^{21}$

Furthermore, according to Endo et al., ${ }^{22}$ barbatic acid inhibited the oxygen evolution complex in spinach thylakoid membranes and also affected the parameters of chlorophyll a (ChL a) fluorescence, with its site of interaction located at PS II. In addition, the targets of lecanorin and gyrophoric acid were located at the watersplitting enzyme level and in one of the redox enzymes in the range of electron transport from $\mathrm{P}_{680}$ to $\mathrm{Q}_{\mathrm{A}}{ }^{23}$ Additionally, a number of natural products also reduce the efficiency of photosynthesis by other means. ${ }^{21}$ Continuing with our studies on fungal products, in the present work we report the herbicidal potential of depsides $\mathbf{1}$ and $\mathbf{2}$, previously isolated from the fungus Cladosporium uredinicola found in fruits of Guava (Figure 1). ${ }^{25}$ These compounds, used at increasing concentrations, affected the different photosynthetic activities, measured with polarographic techniques and fluorescence induction curves of chlorophyll a (ChL a) of PS II.

\section{Experimental}

\section{Isolation of endophyte}

Cladosporium uredinicola was isolated from Psidium guajava pulp fruits. Commercial fruits with no illness symptoms were used. The fruits were bought in São Carlos local trade, São Paulo state, on October 2007. The general procedures adopted for superficial fruits sterilization followed an adapted methodology described by Petrini et al. ${ }^{24}$ Alternating immersions of fruits were done<smiles>Cc1cc(O)c(C)c(OC(=O)c2c(C)cc(O)c(C)c2O)c1</smiles><smiles>Cc1cc(O)c(C)c(OC(=O)c2c(C)cc(OC(=O)c3c(C)cc(O)c(C)c3O)c(C)c2O)c1</smiles>

Figure 1. Depsides produced by $C$. uredinicola in rice media culture, 3-hydroxy-2,5-dimethylphenyl 2,4-dihydroxy-3,6-dimethylbenzoate (1) and 3-hydroxy-2,5-dimethylphenyl 4-[(2,4-dihydroxy-3,6dimethylbenzoyl)oxy]-2-hydroxy-3,6-dimethylbenzoate (2).

in $70 \%$ ethanolic solution, water, sodium hypochloride solution (11\%) and water, applying $1 \mathrm{~min}$ time immersion. After sterilization procedure, little pulp pieces were deposited on Petri dishs containing potato-dextrose-agar (PDA) media and incubated in the dark at $25^{\circ} \mathrm{C}$ for one week. After microorganism growth, the respective brownish colonies were removed from guava fruit pulp, and placed on PDA, resulting in the pure colonies of $C$. uredinicola. This microorganism has been identified by microbial genetics specialists from Federal University of Amazonas (ICB-DFCA/UFAM). The analysis was obtained with $96 \%$ of identity and $100 \%$ of trustworthiness according to comparisons with the genetics data bases.

\section{Extraction and isolation of natural products}

Depsides $\mathbf{1}$ and $\mathbf{2}$ were isolated from fungal ethanolic extract and identified by spectroscopic techniques as previously described..$^{25}$

\section{Chloroplasts isolation and chlorophyll determination}

Intact chloroplasts were isolated from spinach leaves (Spinacea oleracea L.) obtained from a local market as previously described. ${ }^{26,27}$ Chloroplasts were suspended in the following medium: $400 \mathrm{mmol} \mathrm{L}^{-1}$ sucrose, $5 \mathrm{mmol} \mathrm{L}^{-1}$ $\mathrm{MgCl}_{2}, 10 \mathrm{mmol} \mathrm{L}^{-1} \mathrm{KCl}$, and buffered with $0.03 \mathrm{~mol} \mathrm{~L}^{-1}$ $\mathrm{Na}^{+}$tricine at $\mathrm{pH}$ 8.0. They were stored as a concentrated suspension in the dark for $1 \mathrm{~h}$ at $0{ }^{\circ} \mathrm{C}$. Intact chloroplasts were efficiently lysed to yield free thylakoids prior to each experiment by incubating them in the following electron transport medium: $100 \mathrm{mmol} \mathrm{L}^{-1}$ sorbitol, $10 \mathrm{mmol} \mathrm{L}^{-1}$ $\mathrm{KCl}, 5 \mathrm{mmol} \mathrm{L}^{-1} \mathrm{MgCl}_{2}, 0.5 \mathrm{mmol} \mathrm{L} \mathrm{m}^{-1} \mathrm{KCN}$, and $30 \mathrm{mmol} \mathrm{L}^{-1}$ tricine $(N$-tris[hydroxymethyl]methylglicine; 
$N$-[2-hydroxy-1,1-bis(hydroxymethyl)ethyl]glycine) buffer (tris/pH 8 with $\mathrm{KOH}$ ). Chlorophyll concentration was measured spectrophotometrically as reported. ${ }^{28}$

\section{Measurement of non-cyclic electron transport rate}

Light-induced non-cyclic electron transport activity from water to MV was determined by using a Clark type electrode, in the presence of $50 \mathrm{mmol} \mathrm{L}^{-1}$ of $\mathrm{MV}$ as electron acceptor. ${ }^{28}$ Basal electron transport was determined by illuminating chloroplasts (20 $\mu \mathrm{g} \mathrm{mL}^{-1}$ of chlorophyll) during $1 \mathrm{~min}$ in $3.0 \mathrm{~mL}$ of the reacting medium: $100 \mathrm{mmol} \mathrm{L}^{-1}$ sorbitol, $5 \mathrm{mmol} \mathrm{L}^{-1} \mathrm{MgCl}_{2}, 10 \mathrm{mmol} \mathrm{L}^{-1} \mathrm{KCl}, 0.5 \mathrm{mmol} \mathrm{L}^{-1} \mathrm{KCN}$, $30 \mathrm{mmol} \mathrm{L}^{-1} \mathrm{Na}^{+}$-tricine, and $50 \mathrm{mmol} \mathrm{L}{ }^{-1} \mathrm{MV}$ at $\mathrm{pH} 8.0$. The sample was illuminated in the presence or absence of $6 \mathrm{mmol} \mathrm{L}{ }^{-1} \mathrm{NH}_{4} \mathrm{Cl}^{29}$ Phosphorylating non-cyclic electron transport was measured as basal non-cyclic electron transport except that $1 \mathrm{mmol} \mathrm{L}^{-1} \mathrm{ADP}$ and $3 \mathrm{mmol} \mathrm{L}^{-1} \mathrm{KH}_{2} \mathrm{PO}_{4}$ were added to the reaction medium. Uncoupled electron transport from water to MV was tested in the basal non-cyclic electron transport medium, and $6 \mathrm{mmol} \mathrm{L}-1 \mathrm{NH}_{4} \mathrm{Cl}$ was added. All reaction mixture was illuminated with actinic light of a projector lamp (GAF 2660) passed through a $5 \mathrm{~cm}$ filter of a $1 \% \mathrm{CuSO}_{4}$ solution for $1 \mathrm{~min}$.

\section{Uncoupled PS II and PS I electron flow determination}

Electron transport activity was monitored with an YSI (Yellow Springs Instrument) model 5300 oxygen monitors using a Clark electrode. The reaction medium was the same as in electron transport assay. Uncoupled PS II from $\mathrm{H}_{2} \mathrm{O} \rightarrow$ DCBQ was measured by the reduction of DCBQ supported $\mathrm{O}_{2}$ evolutions monitored polarographically. The reaction medium for assaying PS II activity contained the same basal electron transport medium in the presence of $1 \mu \mathrm{mol} \mathrm{L} \mathrm{L}^{-1} 2,5$-dibromo-3methyl-6-isopropyl-1,4-p-benzoquinone) (DBMIB), $100 \mu \mathrm{mol} \mathrm{L}^{-1} \mathrm{DCPIP} / 300 \mu \mathrm{mol} \mathrm{L}^{-1} \mathrm{~K}_{3}\left[\mathrm{Fe}(\mathrm{CN})_{6}\right]$, and $6 \mathrm{mmol} \mathrm{L}^{-1} \mathrm{NH}_{4} \mathrm{Cl}$. Uncoupled PS I electron transport from DCPIP $_{\text {reduced }}$ to MV was determined in a similar form to basal non-cyclic electron transport medium. The following reagents were added: $10 \mu \mathrm{mol} \mathrm{L}^{-1}$ 3-(3,4-dichlorophenyl)1,1-dimethylurea (DCMU), $100 \mu \mathrm{mol} \mathrm{L}^{-1}$ DCPIP, $50 \mu \mathrm{mol} \mathrm{L}^{-1} \mathrm{MV}, 300 \mu \mathrm{mol} \mathrm{L}^{-1}$ ascorbate, and $6 \mathrm{mmol} \mathrm{L}^{-1}$ $\mathrm{NH}_{4} \mathrm{Cl}$. Uncoupled PS I electron transport from reduced phenylmetasulfate (PMS) to MV was determined using KCN poisoned chloroplasts. The reaction medium was the same as in PS I except that $500 \mu \mathrm{mol} \mathrm{L}^{-1}$ $\mathrm{PMS} / 100 \mu \mathrm{mol} \mathrm{L}^{-1}$ ascorbate was used as electron donor to $\mathrm{P}_{700}$ (PS I reaction center), MV as PS I electron acceptor, $10 \mu \mathrm{mol} \mathrm{L}^{-1} \mathrm{DCMU}$ as inhibitor to $\mathrm{Q}_{\mathrm{B}}$ (secondary quinone electron acceptor of PS II), and $6 \mathrm{mmol} \mathrm{L}^{-1} \mathrm{NH}_{4} \mathrm{Cl}$ used as uncoupler to PS I. Cyanide treated chloroplasts were prepared by incubating chloroplasts for $30 \mathrm{~min}$ at $4{ }^{\circ} \mathrm{C}$ in $30 \mathrm{mmol} \mathrm{L}^{-1} \mathrm{KCN}$ and then centrifuged at $8000 \mathrm{~g}$ (Sorvall super T21) for $1 \mathrm{~min}$ and resuspended in the reaction medium. ${ }^{29}$ Moroever, electron paramagnetic resonance (EPR) spectroscopy confirmed the ability of reduced PMS to interact directly with $\mathrm{P}_{700} \cdot{ }^{30,31}$ The $\mathrm{I}_{50}$ value for each activity was extrapolated using the graph of percent activity versus concentration of compounds. $I_{50}$ is the concentration to produce $50 \%$ of inhibition.

\section{Chlorophyll a fluorescence determination}

Chlorophyll a fluorescence was measured with a Hansatech Fluorescence Handy PEA (plant efficiency analyzer) in 10 min dark-adapted chloroplasts $\left(20 \mu \mathrm{g} \mathrm{mL}^{-1}\right)$ at room temperature, ${ }^{8}$ using red light intensity (broad band $650 \mathrm{~nm}$ ) of $3000 \mu \mathrm{mol} \mathrm{m}^{-2} \mathrm{~s}^{-1}$, provided by an array of three light emitting diodes. The pulse duration was $2 \mathrm{~s}$. The reaction medium used was as the one employed in basal non-cyclic electron transport measurements. To monitor $\mathrm{ChL}$ a fluorescence transients, aliquots of dark adapted thylakoids were placed by gravity on filter paper with a dot-blot apparatus (Bio-Rad, United States) to ensure a homogeneous and reproducible distribution of thylakoids in the filter paper and then dipped immediately in $3 \mathrm{~mL}$ of electron transport medium with $300 \mu \mathrm{mol} \mathrm{L}^{-1}$ of the test compound. $^{32,33}$

\section{Results and Discussion}

The depsides tested in this work were re-isolated and identified as reported in a previously publication. ${ }^{25}$ Strucutural similarities of $C$. uredinicola depsides with colletotric acid, ${ }^{34}$ lecanorin ${ }^{23}$ and gyrophoric acid, ${ }^{35}$ suggested that these could behave as lecanorin and gyrophoric acid in the reported effects on thylakoid electron transport and photophosphorylation. ${ }^{23}$

Photophosphorylation can be affected by inhibition of either the redox chain or the $\mathrm{H}^{+}$-ATPase complex or by uncoupling. To elucidate the mode of action of depsides $\mathbf{1}$ and 2 on photophosphorylation, their effects on electron transport rate were investigated. The compounds were tested on basal, phosphorylating and uncoupled electron transport chain from water to MV in freshly lysed spinach chloroplasts. Both inhibited oxygen uptake by illuminated chloroplasts (Figures 2 and 3), and all conditions of electron flow. It was concluded that $\mathbf{1}$ and $\mathbf{2}$ are Hill reaction inhibitors, showing $\mathrm{I}_{50}$ values of 75.0 and $40.0 \mathrm{mmol} \mathrm{L}^{-1}$, respectively, for uncoupled electron transport flow. 


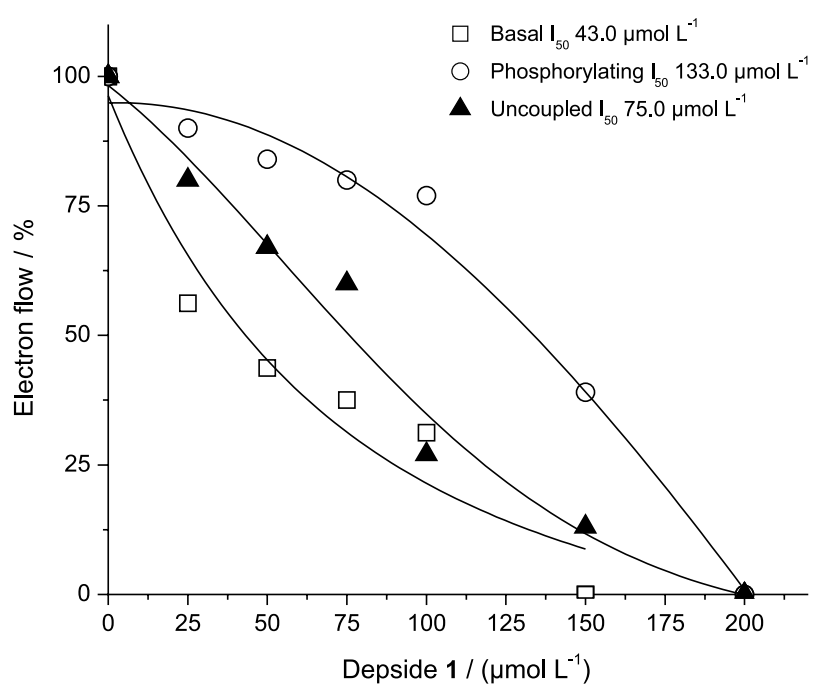

Figure 2. Effect of compound 1 on electron flow (basal, phosphorylating and uncoupled) from water to MV in spinach chloroplasts. Control rate values for electron transport from basal, phosphorylating and uncoupled conditions were 320,610 , and $1200 \mu$ equiv $\mathrm{e}^{-1} \mathrm{~h}^{-1}$ per $\mathrm{mg}$ of $\mathrm{ChL}$, respectively.

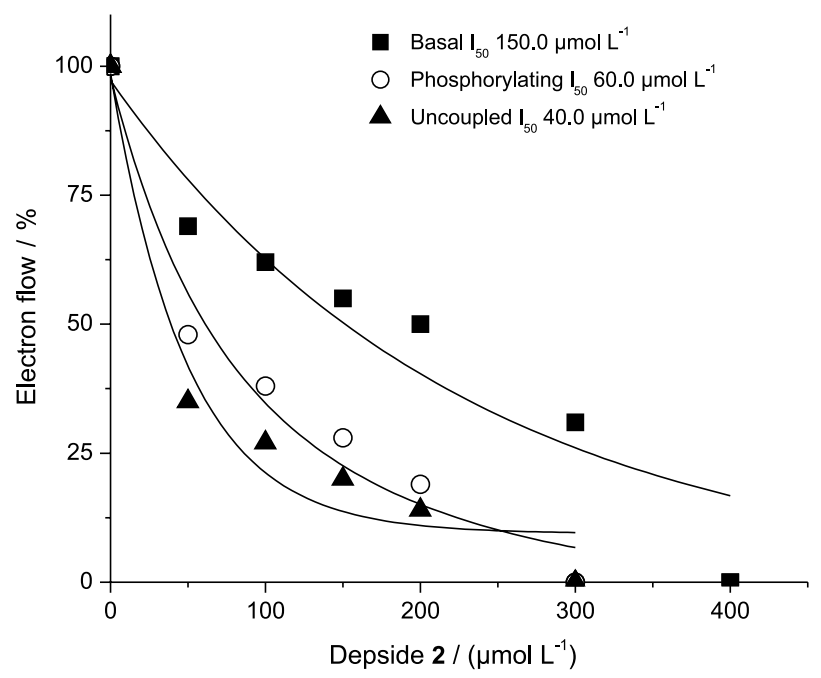

Figure 3. Effect of compound 2 on electron flow (basal, phosphorylating and uncoupled) from water to MV in spinach chloroplasts. Control rate values for electron transport from basal, phosphorylating and uncoupled conditions were 320,610 , and $1200 \mu$ equiv $\mathrm{e}^{-1} \mathrm{~h}^{-1}$ per $\mathrm{mg}$ of $\mathrm{ChL}$, respectively.

To localize the site of inhibition on thylakoid electron transport chain, the effect of $\mathbf{1}$ and $\mathbf{2}$ on PS II and PS I, as well as the partial reactions, were tested using artificial electron donors and electron acceptors and appropriate inhibitors. ${ }^{29}$ Figures 4 and 5 show that $\mathbf{1}$ and $\mathbf{2}$ inhibited both uncoupled PS II electron transport from water to DCBQ and the span of electron flow from water to sodium silicomolybdate by $100 \%$ at 200 and $150 \mathrm{mmol} \mathrm{L}^{-1}$, respectively. These results indicate that $\mathbf{1}$ and $\mathbf{2}$ inhibited PS II at the span of electron transport from water to $Q_{A}$, due to the fact that sodium silicomolybdate accept electrons at $\mathrm{Q}_{\mathrm{A}}$ site. To determine the site of electron transport inhibition of the metabolites between water to $Q_{A}$, electron flows were measured from
DPC (donates electron at $\mathrm{P}_{680}$ ) to DCPIPox (accepts electrons at $\mathrm{Q}_{\mathrm{B}}$ site) in Tris-treated chloroplasts that inhibit the water splitting enzyme activity, and uncoupled with $6 \mathrm{mmol} \mathrm{L}^{-1}$ $\mathrm{NH}_{4} \mathrm{Cl}$ in the presence of $\mathbf{1}$ and $\mathbf{2}$. Table 1 shows that the span of electron transport from $P_{680}$ to $Q_{B}$ was partially inhibited at all concentrations tested. Therefore, the results indicate that the target of $\mathbf{1}$ and $\mathbf{2}$ is located at the donor side of PS II; it interacts at the water-splitting enzyme complex and in the span of electron transport chain from $\mathrm{P}_{680}$ to $\mathrm{Q}_{\mathrm{A}}$. Additionally, uncoupled PS I ( $b_{6} f$ to ferredoxine) electron transport from $\mathrm{DCPIPH}_{2}$ was not affected by the depsides (data not shown). Therefore, depsides are PS II inhibitors acting similar to the commercial herbicide, DCMU.

To corroborate to the polarographic data, selected fluorescence parameters from the OJIP curve were obtained

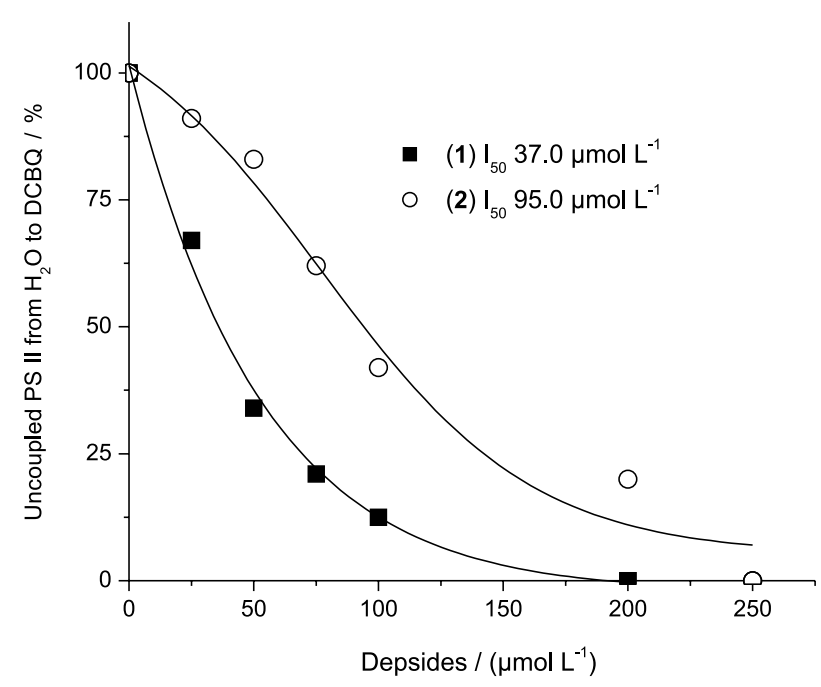

Figure 4. Effect of depsides 1-2 on uncoupled PS II electron flow from $\mathrm{H}_{2} \mathrm{O}$ to DCBQ. Control value rate as $100 \%$ was 400 uequiv $\mathrm{e}^{-1} \mathrm{~h}^{-1}$ per $\mathrm{mg}$ of $\mathrm{ChL}$. Data are average of three replicates.

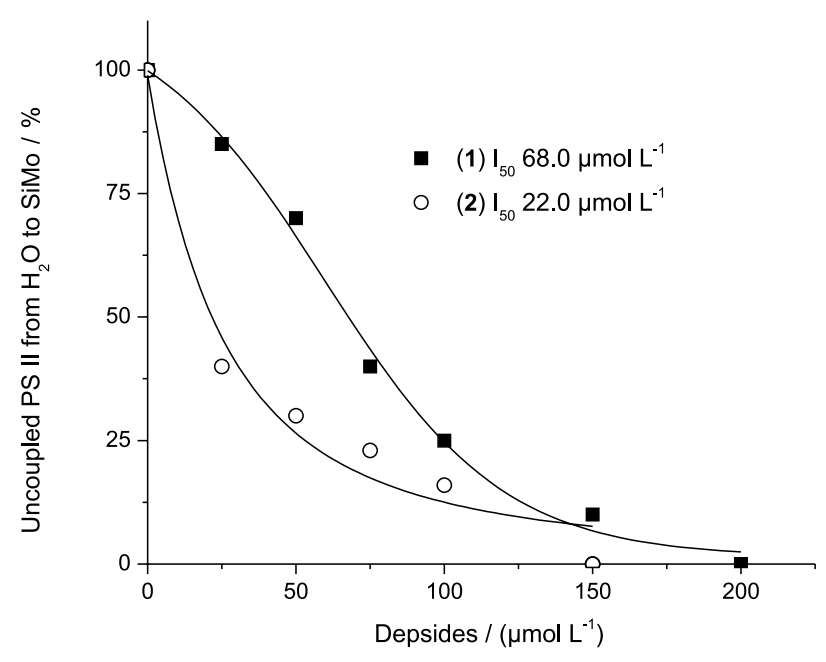

Figure 5. Effect of depsides 1-2 on uncoupled PS II electron flow from $\mathrm{H}_{2} \mathrm{O}$ to SiMo. Control value rate as $100 \%$ was $350 \mu$ equiv $\mathrm{e}^{-1} \mathrm{~h}^{-1}$ per $\mathrm{mg}$ of $\mathrm{ChL}$. Data are average of three replicates. 
Table 1. Effect of the depsides 1-2 on uncoupled PS II electron transport from DPC to DCPIP reduced $_{\text {. }}$

\begin{tabular}{lcccc}
\hline \multirow{2}{*}{$\begin{array}{l}\text { Conc./ } \\
\left(\mathrm{mmol} \mathrm{L}^{-1}\right)\end{array}$} & \multicolumn{4}{c}{ DPC to DCPIP } \\
\cline { 2 - 5 } & $\mathrm{c}$ & $\mathrm{b}$ & $\mathrm{a}$ & $\mathrm{b}$ \\
\hline 0 & 240 & 100 & 240 & 100 \\
50 & 202 & 84 & 228 & 95 \\
100 & 173 & 72 & 184 & 76 \\
200 & 170 & 70 & 150 & 62 \\
300 & 130 & 54 & 125 & 52 \\
\hline
\end{tabular}

${ }^{a}$ Values in $\mathrm{mmol} \mathrm{L}^{-1}$ DCPIP reduced ${ }^{-1}$ per $\mathrm{mg}$ of ChL. ${ }^{\mathrm{b}}$ Values in percent.

with a control, under the effect of depsides, using $10 \mathrm{mmol} \mathrm{L}^{-1}$ of DCMU and $0.8 \mathrm{~mol} \mathrm{~L}^{-1}$ Tris, as positive controls. The area size above the fluorescence curve between $\mathrm{F}_{0}$ an $\mathrm{F}_{\mathrm{M}}$, which is proportional to the pool size of the electron acceptors $\mathrm{Q}_{\mathrm{A}}$ on the reducing side of PS II, decreased under higher concentrations of $\mathbf{1}$ and $\mathbf{2}$ (Table 2). Chlorophyll a induction curves of thylakoids showed an OJIP (control curve at Figure 6) sequence of transients similar to that previously described for plants, green algae, and cyanobacteria. ${ }^{32}$ Figure 6 also shows the effect of $\mathbf{1}$ and $\mathbf{2}$ at $300 \mathrm{mmol} \mathrm{L}^{-1}$ on the fluorescence induction curves on freshly lysed intact chloroplasts. Addition of $10 \mathrm{mmol} \mathrm{L}^{-1}$ DCMU resulted in a fast rise of the fluorescence yield during the first $2 \mathrm{~ms}$ of illumination, transforming the OJIP transient into an OJ sequence (DCMU curve at Figure 6), indicating that DCMU displaces the secondary quinone acceptor, $\mathrm{Q}_{B}$, from its binding site at the $\mathrm{D}_{1}$ protein of PS II. ${ }^{36,37}$

Addition of $0.8 \mathrm{~mol} \mathrm{~L}^{-1}$ Tris, $\mathrm{pH} 8.0$, a well-known donor site inhibitor of PS II, ${ }^{38}$ resulted in the formation of a $\mathrm{K}$ phase followed by a dip; the $\mathrm{K}$ step arises when

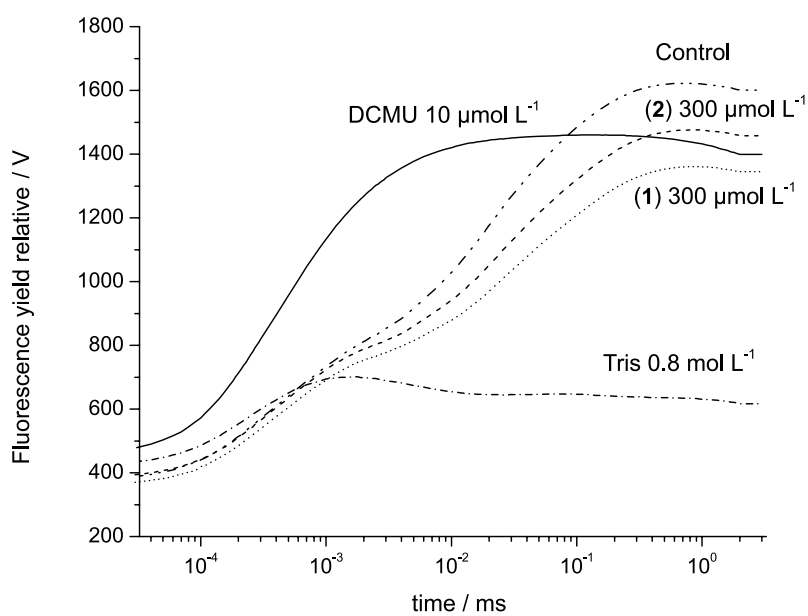

Figure 6. Fluorescence rise kinetics of freshly lysed broken chloroplasts infiltrated with $\mathbf{1}$ and $\mathbf{2}$ at $300 \mathrm{mmol} \mathrm{L}^{-1}$, DCMU and Tris treated thylakoid. Control chloroplasts are shown for comparison. $\mathrm{ChL}$ a fluorescence induction curves were measured at room temperature. Data represent the averages of ten replicates.
Table 2. Effect of $\mathbf{1}$ and $\mathbf{2}$ on fluorescence parameters of thylakoids previously incubated for $10 \mathrm{~min}$, in the dark and with $0.8 \mathrm{~mol} \mathrm{~L}^{-1}$ Tris, pH 8.0.

\begin{tabular}{lcccc}
\hline Compound & $\mathrm{F}_{0}$ & $\mathrm{~F}_{\mathrm{M}}$ & $\mathrm{F}_{\mathrm{V}} / \mathrm{F}_{\mathrm{M}}$ & Area \\
\hline Control & 371 & 1622 & 0.776 & 49135 \\
DCMU $10 \mathrm{mmol} \mathrm{L}^{-1}$ & 429 & 1460 & 0.706 & 2056 \\
Tris $0.8 \mathrm{~mol} \mathrm{~L}^{-1}$ & 410 & 701 & 0.415 & 0 \\
(1) $300 \mathrm{mmol} \mathrm{L}^{-1}$ & 363 & 1436 & 0.746 & 32920 \\
(2) $300 \mathrm{mmol} \mathrm{L}^{-1}$ & 346 & 1476 & 0.749 & 33903 \\
\hline
\end{tabular}

the electron flow to the acceptor side exceeds the electron flow from the donor side. ${ }^{33}$ The K step appears clearly and consists of a rapid rise to a maximum (at $300 \mathrm{~ms}$ ) followed by a decrease to a level close to $\mathrm{F}_{0}$ (Figure 7). The decrease of fluorescence after the $\mathrm{K}$ seems to be a reasonable estimate because a rather strong inhibition of the electron transport from $Q_{A}{ }^{-}$to $Q_{B}$ occurs at the temperature when the $\mathrm{K}$ step appears. ${ }^{39}$ The origin of the decrease of fluorescence after the K step (Figure 7) in the oxidation of $\mathrm{Q}_{\mathrm{A}}^{-}$by the subsequent electron acceptors, i.e., a dynamic equilibrium between PS II and PS I is improbable..$^{33,40}$ Steps J and I are absent from the transient, as shown by heat-treated samples, ${ }^{41}$ in which conditions the electron flow from $\mathrm{P}_{680}$ to $\mathrm{Q}_{\mathrm{A}}$ causes the formation of the $\mathrm{K}$ step.

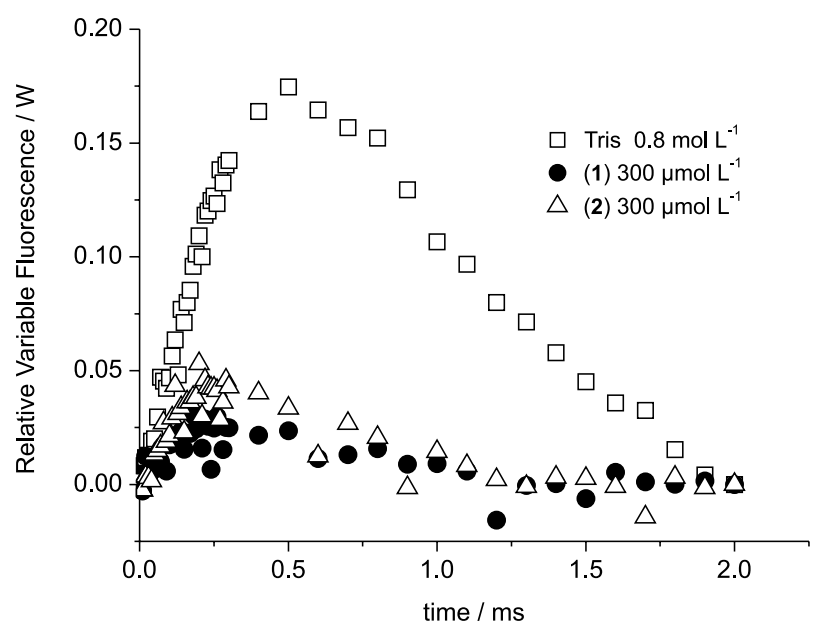

Figure 7. Appearance of the K-band at about $300 \mathrm{~ms}$. Difference of each curve from the control with normalized relative variable fluorescence on the amplitude $\mathrm{F} j-\mathrm{F}_{0}$. Compounds $\mathbf{1}(\bullet)$ and $\mathbf{2}(\triangle)$ at $300 \mathrm{mmol} \mathrm{L}^{-1}$ and broken chloroplasts incubated with $0.8 \mathrm{~mol} \mathrm{~L}^{-1}$ Tris ( $\square$ ).

The fast initial fluorescence rise is due to the reduction of $\mathrm{Q}_{\mathrm{A}}$ followed by the reduction of $\mathrm{P}_{680}^{+}$by $\mathrm{Z}$ without the direct participation of the oxygen evolution complex (OEC). The subsequent reduction in fluorescence yield apparently results from the opening of the reaction center by reoxidation of $\mathrm{Q}_{\mathrm{A}}$ and/or accumulation of $\mathrm{P}_{680}^{+}$, both of which are effective fluorescence quenchers. ${ }^{33}$ However, 
the analysis of the $\mathrm{ChL}$ a fluorescence transient in this work indicates that the water-splitting enzyme was mildly blocked by 1 and 2 (Figures 6 and 7). At a $300 \mathrm{mmol} \mathrm{L}^{-1}$ concentration of $\mathbf{1}$ and $\mathbf{2}$, the area size above the fluorescence curve between $\mathrm{F}_{0}$ and $\mathrm{F}_{\mathrm{M}}$, which is proportional to the pool size of the electron acceptors $\left(\mathrm{Q}_{\mathrm{A}}\right)$ on the reducing side of PS II, decreased 33 and $31 \%$, respectively (Table 2). These decreased values indicate that the electron transfer to the quinone pool size is partially blocked by the metabolites.

Figure 8 shows the effect of compounds at $300 \mu \mathrm{mol} \mathrm{L}^{-1}$ increasing the parameters Sum K and $\mathrm{Kn}$ in $20 \%$ of efficiency. Photochemical (Kp) and non photochemical $(\mathrm{Kn})$ excitation rate constant raised (quenching effect), suggesting an increase effect on fluorescence of $\mathrm{ChL}$ a kinetics results (and calculated parameters) in thylakoids. The probability that a trapped exciton moves an electron into the electron transport chain beyond $\mathrm{Q}_{\mathrm{A}}{ }^{-}$and the electron transport per cross section $\left(\mathrm{ET}_{0} / \mathrm{CS}_{0}\right)$, confirm the photophosphorylation results of the compound, which behave as Hill reaction inhibitors. The principal effect observed on PI(abs) indicated index performance absortion, a decrease of 40 and $35 \%$ for $\mathbf{1}$ and $\mathbf{2}$, respectively, compared with control. These results suggest that the process is only occurring on PS II, corroborating the results of reactive site location (inhibition of electron transport, polarographic data).

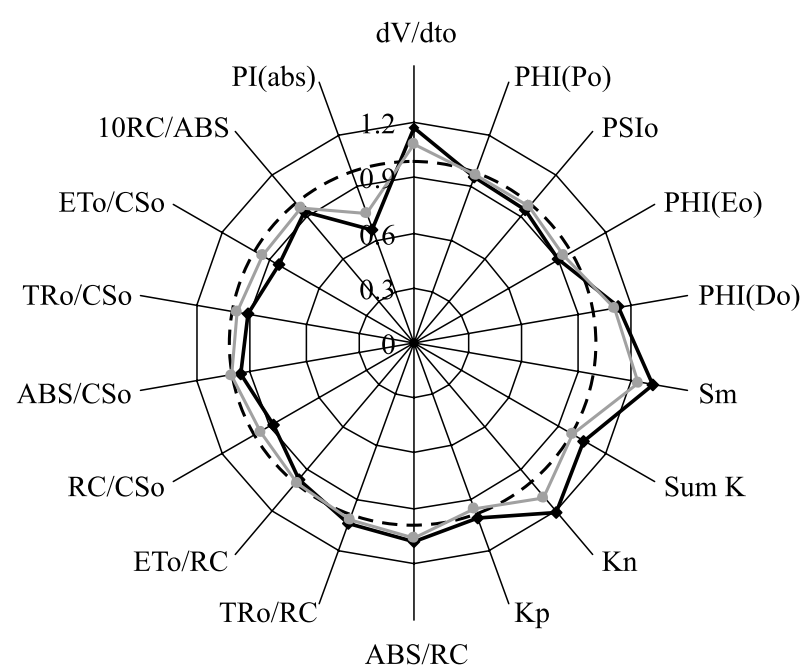

Figure 8. Radar plot graphs showing the effects of depsides on chlorophyll a fluorescence parameter calculated from OJIP curve. Both compounds were infiltrated on spinach leaf disk at $300 \mathrm{mmol} \mathrm{L}^{-1}$, compound $\mathbf{1}(\mathbf{\square})$, compound $2(\bullet)$, and compared with the control leaf disc (dashed black line). The incubation time with the compounds for each treatment was $12 \mathrm{~h}$, and then adapted in the dark for $30 \mathrm{~min}$.

\section{Conclusions}

In this study we have demonstrated that two depsides (1-2) isolated from the endophytic fungus
Cladosporium uredinicola, act as a Hill reaction inhibitors in a similar way as other natural products such as lasiodiplodin, ${ }^{8}$ siderin, ${ }^{42}$ trachyloban-19-oic acid ${ }^{43}$ xanthorrhizol ${ }^{44}$ and tricolorin A. ${ }^{45}$ Polarographic measurements and chlorophyll a fluorescence measurements indicate that $\mathbf{1}$ and $\mathbf{2}$ inhibited partially the water-splitting enzyme, and have their sites of interaction localized at PS II $\left[\mathrm{P}_{680}-\mathrm{Q}_{\mathrm{A}}\right]$, i.e., inhibited both sites of PS II, the acceptor and donor sides. Therefore, these compounds may be good candidates as lead structures, which could be optimized for the development of new herbicides.

\section{Note from the Editor}

The structure of $\mathbf{2}$ was wrongly assigned in reference 25 as 3-hydroxy-2,5-dimethylphenyl 3-[(2,4-dihydroxy-3,6dimethylbenzoyl)oxy]-6-hydroxy-2,4-dimethylbenzoate. An erratum has been sent by the authors to Helv. Chim. Acta.

\section{Acknowledgments}

We gratefully acknowledge financial support from CAPES (Coordenação de Aperfeiçoamento de Pessoal de Nível Superior), FAPESP (Fundação de Amparo à Pesquisa do Estado de São Paulo) and CNPq (Conselho Nacional de Desenvolvimento Científico e Tecnológico). We thank Dr. Blas Lotina-Hennsen (UNAM) and Beatriz King-Díaz (UNAM) for technical assistance.

\section{References}

1. Dayan, F. E.; Cantrell, C. L.; Duke, S. O.; Bioorg. Med. Chem. 2009, 17, 4022.

2. Evidente, A.; Cimmino, A.; Berestetskiy, A.; Andolfi, A.; Motta, A.; J. Nat. Prod. 2008, 71, 1897.

3. Macias, F. A.; Oliveros-Bastidas, A.; Marin, D.; Carrera, C.; Chinchilla, N.; Molinillo, J. M. G.; Phytochem. Rev. 2008, 7, 179.

4. Duke, S. O.; Evidente, A.; Fiore, M.; Rimando, A. M.; Dayan, F. E.; Vurro, M.; Christiansen, N.; Looser, R.; Hutzler, J.; Grossmann, K.; Pestic. Biochem. Physiol. 2011, 100, 41.

5. Dayan, F. E.; Owens, D. K.; Duke, S. O.; Pest Manage. Sci. 2012, 68, 519.

6. Yuzikhin, O.; Mitina, G.; Berestetskiy, A.; J. Agric. Food Chem. 2007, 55, 7707.

7. Evidente, A.; Punzo, B. V.; Andolfi, A.; Berestetskiy, A.; Motta, A.; J. Agric. Food Chem. 2009, 57, 6656.

8. Veiga, T. A. M.; Silva, S. C.; Archundia-Camacho, F.; Rodrigues-Filho, E.; Vieira, P. C.; Fernandes, J. B.; da Silva, M. F. G. F.; Muller, M. W.; Lotina-Hennsen, B.; J. Agric. Food Chem. 2007a, 55, 4217. 
9. Berry, E. A.; Li-Shar, H.; Dong-Woo, L.; Daldal, F.; Nagai, K.; Minagawa, N.; Biochim. Biophys. Acta, Bioenerg. 2010, 1797, 360.

10. Evidente,A.;Andolfi,A.; Cimmino,A.;Vurro, M.; Fracchiolla, M.; Harudattan, R.; J. Agric. Food Chem. 2006, 54, 1779.

11. Berestetskiy, A.; Dmitriev, A.; Mitina, G.; Lisker, I.; Andolfi, A.; Evidente, A.; Phytochemistry 2008, 69, 953.

12. Dayan, F. E.; Romagni, J. G.; Duke, S. O.; J. Chem. Ecol. 2000 , 26, 2079.

13. Worgoter, E. S.; Nat. Prod. Rep. 2008, 25, 188.

14. Peng-Cheng, L.; Zhu-Ping, X.; Rui-Qin, F.; Huan-Qiu L.; HaiLiang Z.; Chang-Hong, L.; Eur. J. Med. Chem. 2009, 44, 1779.

15. Nielsen, P. J.; Nielsen, P. H.; Frisvad, J. C.; Phytochemistry 1999, 50, 263.

16. Kumar, S. K. C.; Muller, K.; Eur. J. Med. Chem. 2000, 35, 405.

17. Neamati, N.; Hong, H.; Mazunder, A.; Wang, S.; Sunder, S.; Milne, G. W. A.; Proksa, B.; Pommier, Y.; J. Med. Chem. 1997, $40,942$.

18. Lawrey, J. In Allelopathy: Organisms, Processes and Applications; Inderjit, K.; Oakshim, K. M. M.; Einhelling, F. A., eds.; American Chemical Society: Washington, DC, 1995.

19. Dayan, F. E.; Romagni, J. G.; Pestic. Outlook 2001, 12, 229.

20. Romagni, J. G.; Dayan, F. E. In Advances in Microbial Toxin Research and its Biotechnological Exploitation; Upadhyay, R. K., ed.; Kluwer Academic/Plenum Publisher: New York, NY, 2002.

21. Dayan, F. E.; Zaccaro, M. L. de M.; Pestic. Biochem. Physiol. 2012, 102, 189.

22. Endo, T.; Takahagi, T.; Kinoshita, Y.; Yamamoto, Y.; Sato, F.; Biosci. Biotechnol. Biochem. 1998, 62, 2023.

23. Rojas, I. S.; Lotina-Hennsen, B.; Mata, R.; J. Nat. Prod. 2000 , 63, 1396.

24. Petrini, O.; Sieber, T. N.; Toti, L.; Viret, O.; Nat. Toxins 1992 , 1,185 .

25. Medeiros, L. S.; Murgu, M.; de Souza, A. Q. L.; RodriguesFilho, E.; Helv. Chim. Acta 2011, 94, 1077.

26. Lotina-Hennsen, B.; Achnine, L.; Macias, R. N.; Ortiz, A.; Hernandez, J.; Farfan, N.; Aguilar, M. I.; J. Agric. Food Chem. 1998, 46, 724 .

27. Mills, J. D.; Mitchell, P.; Schurmann, P.; FEBS Lett. 1980, 191, 144.

28. Strain, H. H.; Cope, T.; Svec, M. A.; Methods Enzymol. 1971, 23,452 .
29. Allen J. F.; Holmes, N. G. In Photosynthesis. Energy Transduction. A Practical Approach; Hipkins, M. F.; Baker, N. R., eds. IRL Press: Oxford, UK, 1986, pp. 103-1141.

30. Izawa, S.; Winget, C. D.; Good, N. E.; Biochem. Biophys. Res. Commun. 1972, 22, 223.

31. Izawa, S.; Kraayennhof, R.; Ruuge, E. K.; Biochim. Biophys. Acta 1973, 314, 328.

32. Strasser, R. J.; Srivastava, A.; Govindjee; Photochem. Photobiol. 1995, 61, 32 .

33. Strasser, R. J.; Photosynth. Res. 1997, 52, 147.

34. Zou, W. N.; Meng, J. C.; Chen, G. X.; Zhang, T. Y.; Tan, R. X.; J. Nat. Prod. 2000, 63, 1529.

35. Narui, T.; Sawada, K.; Takatsuki, S.; Okuyama, T.; Culberson, C. F.; Culberson, W. L.; Shibata, S.; Phytochemistry 1998, 48, 815 .

36. Velthuys, B. R.; FEBS Lett. 1981, 126, 277.

37. Wraight, C. A.; Isr. J. Chem. 1981, 21, 348.

38. Britt, R. D. In Oxygenic Photosynthesis: The Light Reactions (Advances in Photosynthesis and Respiration); Ort, D. R.; Yocum, C. F., eds.; Kluwer Academic Publishers: Amsterdam, The Netherlands, 1996.

39. Lázar, D.; Pospisil, P.; Naus, J.; Photosynthetica 1999, 37, 255.

40. Srivastava, A.; Guissé, B.; Greppin, H.; Strasser, R. J.; Biochim. Biophys. Acta 1997, 1320, 95.

41. Vazquez-Gonzalez, R.; King-Diaz, B.; Aguilar, M. I., Diego, N.; Lotina-Hennsen, B.; J. Agric. Food Chem. 2006, 54, 1217.

42. Veiga, T. A. M.; Vazquez-Gonzalez, R.; Oiano-Neto, J.; da Silva, M. F. G. F.; King-Diaz, B.; Lotina-Hennsen, B.; Arch. Biochem. Biophys. 2007b, 465, 38.

43. Hernandez-Terrones, M. G.; Aguilar, M. I.; King-Diaz, B.; Lotina-Hennsen, B.; Pestic. Biochem. Physiol. 2003, 77, 12.

44. González-Bernardo, E.; King-Díaz, B.; Delgado, G.; Aguilar, M. I.; Lotina-Hennsen, B.; Physiol. Plant. 2003, 119, 598.

45. Achnine, L.; Moreno-Sanchez, R.; Iglesias-Prieto, R.; PeredaMiranda, R.; Lotina-Hennsen, B.; Physiol. Plant. 1999, 106, 246.

Submitted: March 8, 2012

Published online: August 2, 2012

FAPESP has sponsored the publication of this article. 